\title{
6 Of Ethnicity, Manipulation and Observation: the 1992 and 1997 Elections in Kenya
}

\author{
D. Foeken and T. Dietz
}

\section{INTRODUCTION}

On 29 December 1992, the first multi-party elections - both presidential and parliamentary - since 1966 were held in Kenya. Exactly five years later this happened again. Not only in Kenya, but also in the international community, these elections were followed with special interest, for several interrelated reasons: (1) such elections are considered a major aspect of the 'democratization' process which has been imposed by the western donors on many African states; (2) Kenya has always been a very Western-oriented, open, capitalist and politically fairly stable country amidst a group of countries being quite different in these respects; (3) although less than in the past, it still has strategic importance for the Western countries (for example, Mombasa was an important harbour during the Gulf War); and (4) Kenya is a major 'outlet' for substantial Western donor funds.

The aim of this paper is twofold. First, the results of the elections are analysed in terms of ethnicity and various kinds of manipulation. Second, the importance of election observation is assessed. The two aims are interrelated: given the usual way of election observation (that is, only during a very short period centred around the actual polling day), does observation lead to less manipulation, that is, to more 'free and fair' elections than otherwise? One could go even further: given the ethnic determination of the election results in Kenya, does observation make sense? In the final section of this paper, a cautious answer to these questions is given. 
The paper was largely written before the elections of 1997; hence, the main part of it is about the 1992 elections. The 1997 elections are dealt with in the final section, discussing briefly the changes that occurred during the months preceding the polls - including important changes as far as election observation is concerned - as well as the results.

\section{BRIEF HISTORICAL BAGKGROUND}

In 1989, the Kenyan population counted about 25 million people, subdivided into some 40 ethnic groups. None of the ethnic groups dominates in terms of size. The largest group are the Kikuyu (21 per cent), mainly living in the central part of the country. Then come the Luhya (14 per cent) in western Kenya, the Luo (13 per cent) near Lake Victoria, the Kalenjin (11 per cent) in the central Rift Valley, the Kamba (11 per cent) living east and south-east of Nairobi, the Kisii ( 6 per cent) in the south-west and the Meru ( 5 per cent) living east of Mount Kenya. All these groups consist of several subgroups. For instance, the Luhya are known for their internal rivalries, while there is also not much of a group feeling among the different Kikuyu subgroups. However, among the Kalenjin such a group feeling has become apparent since the end of the 1970s (or has been created since Daniel arap Moi, a Kalenjin himself, became president in 1978). During the colonial period, nobody ever mentioned this group as an entity but talked of smaller ethnic groups like the Nandi, the Kipsigis, the Pokot and the Tugen.

After a bloody guerrilla war, known as the Mau Mau, of especially the Kikuyu in the 1950 s against the British colonial administration and its African collaborators, Kenya obtained its independence in 1963. Jomo Kenyatta, a Kikuyu, became the first president. During the period prior to independence two political movements were formed, the Kenya African National Union (KANU) and the Kenya African Democratic Union (KADU). KANU combined Kikuyu and Luo interests, while KADU found its political base among some smaller ethnic groups, mainly in the Rift Valley. KANU stood for relatively radical policies, with slogans like 'African socialism' and a prefcrence for a strong central state. KADU represented more moderate political ideas and adhered to a decentralized state 
apparatus and more room for private initiative. The first president, Kenyatta, originated from KANU, while the incumbent president, Moi, was one of the leaders of KADU.

Almost immediately after independence, the two parties melted together into one KANU and most leaders soon moved towards political middle positions. This resulted, in 1966, in the secession of a group led by the first vice-president, Jaramogi Oginga Odinga, a Luo. These dissidents founded the radical Kenya Peoples Union (KPU). In 1969 this party was forbidden by the government and its leaders were put in prison. Hence, a de facto one-party state came into existence. However, within the one party, KANU, there were strong differences of opinion as well as a growing resistance to the concentration of power and wealth in the hands of a small Kikuyu group around president Kenyatta.

Kenyatta died in 1978 and was succeeded by Daniel arap Moi, who had been vice-president for ten years. Since Moi was a Tugen, a Kalenjin subgroup, this marked a new era in which political and economic power shifted to the Kalenjin. Of course, especially during the first years of Moi's presidency, this was a precarious process, but by skilfully manoeuvring he succeeded in gradually strengthening his position. He survived a coup attempt in 1982 and from then on he transformed the only permitted political party, KANU, into a state apparatus in his hands and the coterie surrounding him. Kenya had become a de jure one-party state.

\section{ETHNICITY AND TERRITORIALITY ${ }^{1}$}

Despite more than forty years of 'nation building', subnational/ethnic identities are still very strong, and under President Moi's leadership they have intensified. The 'ethnic question' became a major item at the elections of 1992, and the 'ethnic cleansing' that started in some arcas in 1991 (and again occurred in 1997) still has the potential to provoke all-out ethnic warfare and to break the country apart in ethnic zones. If 'ethnicity' has such a potentially devastating power, how 'ethnic' is Kenya? It is interesting to look at the ethnodemographic trends in Kenya before the 1992 elections. After defining 'ethnic clusters'2 and 'ethnic home areas's we havc 
looked at the changes in the level of concentration of the various ethnic clusters in these home areas, comparing the census years 1969, 1979 and 1989. With one small exception all ethnic clusters in Kenya became less concentrated in their home areas, or, to say it the other way around, became more dispersed. Demographically speaking a considerable ethnic deconcentration took place. The pace of deconcentration was much faster between 1969 and 1979 than during the following decade, though (with two exceptions). Nevertheless, despite the general tendency of dispersal, most ethnic clusters are still rather concentrated in their 'home areas': the Coastal Bantu and the Meru cluster leading with more than 90 per cent, followed by Kisii, Maasai, Somali, Boran, Kamba and Luo with more than 75 per cent. The Luhya, Kalenjin, Kikuyu and Turkana are the groups with the highest dispersal outside their 'home areas'.

We can also look at the changes in ethnic homogencity at the level of the districts; for instance, the proportion of the district population taken up by the major ethnic group. It appears that most Kenyan districts were less homogeneous in 1989 than in 1969. However, there is a different overall trend 1969-79 and 1979-89. Compared to 1969,75 per cent of all districts were more heterogeneous in 1979. Out of those 30 districts 18 showed the same trend between 1979 and 1989, but 12 showed a reversed trend of ethnic homogenization during the 1980 s. $^{4}$ In addition, seven districts had a trend of ethnic homogenization during both periods.' This means that during the $1980 \mathrm{~s}$ - the first decade of President Moi's era - almost half of the Kenyan districts experienced an ethnic homogenization trend, with examples from almost all ethnic groups. Looking at it in a longer time perspective, the ethnic cleansing during the beginning of the 1990s can thus be seen as the violent continuation of a process that started at least a decade earlier.

\section{'DEMOGRATIZATION'}

From 1990 onwards, there was so much pressure for democratization from both internal and external forces that Moi had to give in. However, he continuously stressed that multi-partyism would lead to ethnic struggles. And indeed, it is well known that 
a group of political leaders around him did everything to make this a self-fulfilling prophecy. From the start of the political campaigns, ethnic violence took place, first between Kalenjin and Luhya, thereafter extended to bloody 'tribal clashes' between Kalenjin and Luo, between Kalenjin and Kikuyu, and between Maasai and Kikuyu, while the endemic violence in the northern pastoralist areas developed into a chaos of robberies and looting.

In the beginning of the political campaign for the elections of December 1992 it looked as if the political opposition was heading for an easy victory, since the political dominance of Moi's KANU was limited to the Rift Valley. However, in the course of 1992, the opposition, led by veteran politicians who were each others rivals, fell apart into two main groupings: the Democratic Party (DP) of the former vice-president Mwai Kibaki (a Kikuyu) and the Forum for the Restoration of Democracy (FORD) headed by Oginga Odinga (Luo) and by Kenneth Matiba (Kikuyu), a former minister. A few months before the elections, FORD fell apart into a group led by Matiba (FORD-Asili) and a group led by Oginga Odinga (FORD-Kenya).

A united opposition would easily have won the presidential elections of 29 December 1992 . Instead, with only 36 per cent of the votes, Moi was re-elected. And because of the constituency voting system after British design, KANU won an absolute majority in parliament: 100 of the 188 seats, against 31 for FORDAsili, 31 for FORD-Kenya, 23 for the DP and 3 for smaller parties.

\section{ETHNIC VOTING}

Kenya's political system is characterized by ethnic voting. One can speak of 'political ethnicity' when several ethnic groups develop political activities bascd on their claims to ethnic consciousness (ethnicity in this context refers to a 'we-feeling', an identity based on references to certain perceived (or alleged) common characteristics, which usually include a common language and a common territory but not necessarily so). Closely related to political ethnicity is political clientelism. The political leader has to assure himself of as many political 'clients' as 
possible in order to safeguard his position. He finds these clients primarily among his own ethnic group. In case of competition between political leaders of one and the same ethnic group, ethnic groups may vote divided, mostly along clan lines. The result is that political parties in Kenya (and in many other African countries as well) are not based on a political programme but on ethnicity, in which ethnic self-interest prevails.

How ethnic were the Kenyan elections of 1992? When looking at the results of the presidential elections at the provincial level, Map 6.1 shows that Moi obtained a majority not only in his 'own' Rift Valley Province, but also in Coast and Northeastern Provinces. The DP candidate, Mwai Kibaki, was strong in one province only (Eastern). The third candidate, Kenneth Matiba (FORD-Asili), had his 'clients' first of all in Central Province and in Nairobi, while Oginga Odinga dominated in Nyanza Province. Only in Western Province was voting strongly divided, mainly between Moi and Matiba, reflecting the two main factions within the Luhya group.

At the district level, ethnic voting was even more conspicuous, which could be expected, since most districts were ethnically defined. For instance, in those districts in Rift Valley Province with a Kikuyu or Luhya majority, Moi lost. In the districts of Eastern Province with groups most related to the Kikuyu, Moi also did not achieve a majority of the votes. Equally revealing is the fact that Oginga Odinga found no support in Kisii, a district in Nyanza Province which is not inhabited by Luo but by Gusii. Finally, the sharing of the votes among the four presidential candidates in the two main urban centres, Nairobi and Mombasa, reflects the ethnic heterogeneity in these areas.

The results of the general election showed a similar pattern. Besides the Kalenjin votes, President Moi's KANU obtained its support among the pastoralist groups (Turkana, Maasai, Somali, Samburu, Boran), among the coastal Mijikenda, as well as among part of the Luhya group in Western Province. These were also the regions where KADU won in the early sixties. The Democratic Party won in the northern Kikuyu districts, in the nearby Meru and Embu areas, and in some Kamba constituencies. FORD-Asili obtained a majority in the southern Kikuyu districts and in Kakamega where Matiba, the FORD-Asili leader, had formed an alliance with a popular Luhya politician. 
Map 6.1 Kenyan presidential elections 1992: results by province (\% of votes for the four main candidates)

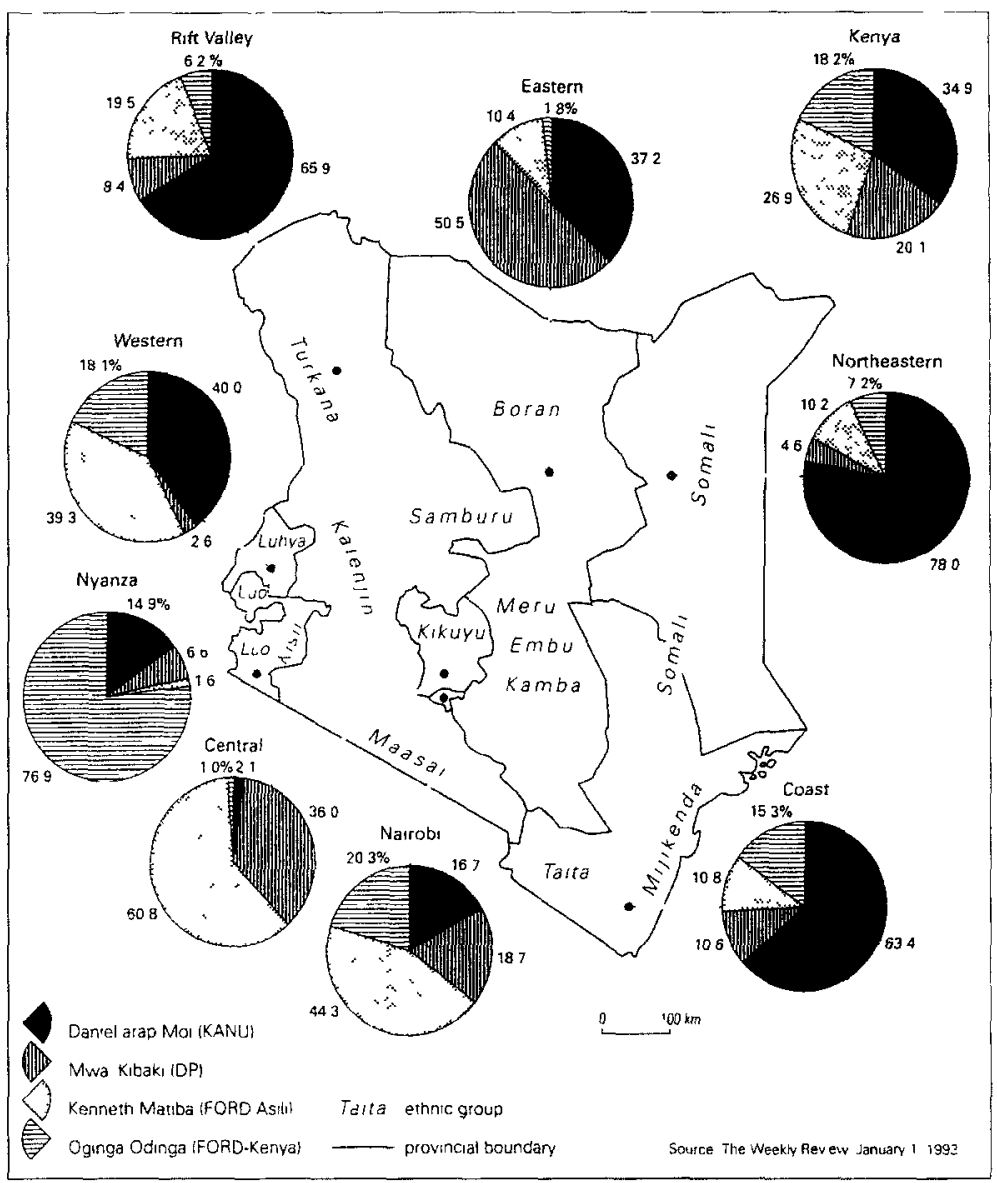

Most of the Nairobi seats went to FORD-Asili, too. Finally, FORD-Kenya, the party of Luo leader Oginga Odinga, won in the whole Luo region. Elsewhere in Kenya, FORD-Kenya won only a few seats, such as in Mombasa where the party had accepted a number of candidates from the Islamic Party of Kenya which had been cxcluded from the election.

Looking at the ethnic background of the elected opposition members of parliament, we see that 67 per cent of the FORD- 
Asili members were Kikuyu, 61 per cent of FORD-Kenya Luo and 52 per cent of the Democratic Party again Kikuyu. In KANU, however, not a single Luo or Kikuyu won a seat. Among the KANU members of parliament, we find all Kalenjin representatives, 12 out of 17 elected Kamba from the south-east, 9 out of 10 elected Somali from the north-east, all 6 elected Maasai, 6 out of 9 elected Gusii, as well as representatives from all the smaller ethnic groups. The numerically second group in Kenya, the Luhya, was strongly divided: 9 representatives for FORD-Asili, 7 for KANU and 5 for FORD-Kenya. Despite this, the influential Kenyan weekly The Weekly Revnew wrote: 'The seventh parliament will be a living example of the reality of ethnic politics in Kenya.' Even in the multicultural capital Nairobi ethnic voting seemed to have been dominant. The percentages of votes for FORD-Asili and FORD-Kenya reflected the percentages of the population being Kikuyu and Luo, respectively.

\section{LEGAL MANIPULATION}

In retrospect, President Moi and his party had an easy victory in the 1992 elections. A few months before the day the elections were held (29 December), their prospects were not so bright, however. The opposition was still fairly united: that is, the Democratic Party and FORD. Especially the latter party, combining about half the Kikuyu and the whole Luo communities, as well as a then still unknown part of the Luhya community (in short: based on the support from the three largest ethnic groups), formed a formidable threat for both the president and KANU. Indeed, a candidate of any combination of the three main opposition parties would have won more votes than Moi. However, even in case of a united opposition, becoming the new president was another thing.

In August 1992, the Constitution of Kenya (Amendment) Bill passed the Kenyan parliament. Among other things, this bill made it mandatory for a successful presidential candidate to muster at least 25 per cent of the votes in at least five (out of eight) provinces (besides the requirements of having the greatest number of votes and being elected a member of parliament for a constituency). In case none of the candidates would 
achieve this, a run-off should have to be held between the two leading candidates. What the bill did not specify were various other possibilities. What had to be done if the leading candidate did not meet this requirement but the second one did? And what had to happen if after the run-off elections, the two candidates still did not muster the 25 per cent clause? At the time of the passing of the bill, these possibilities were not merely theoretical. Nevertheless, the bill sailed smoothly through parliament without any amendments and with only one vote against. This was less surprising than it may seem. Parliament was made up of members of only one party, KANU, and it was widely believed that if there was a party and a presidential candidate capable of meeting this requirement, it was KANU and Moi. Perhaps more surprising was the silence from the opposition. An explanation might be the one given by the attorney-general, Amos Wako, asking: 'Are [the opposition] admitting that the current president can fulfil that 25 per cent requirement and that any other presidential candidate cannot?' (The Weekly Review, 14 Aug. 1992: 15).

If this requirement can be regarded as a strong, legal move towards the re-election of president Moi, another article in the same bill had to safeguard KANU's governing power. The bill also mandated the candidate who was elected president to form a government from among the members of his own political party, even if that party would not have the parliamentary majority. In other words, as long as Moi would be re-elected, KANU would always retain (complete) power. The clause also prevented the other parties from forming a coalition government in case one of the opposition candidates might win the presidential elections. It is remarkable that this clause passed even more unnoticed than the 25 per cent requirement. Perhaps it is an indication that in the end all candidates and parties aim for the same: absolute majority, meaning unshared power.

What was more controversial, however, was the Electoral Commission, which had responsibility for the organization and conduct of the elections. According to the Kenyan constitution, the Commission is appointed by the president. In order to be acceptable to all parties, it was evident that at least its chairman, Justice Zacchaeus Chesoni, would have to be considered by everybody as being impartial. The opposition leaders were 
never consulted, however, and Chesoni was widely regarded as a puppet of president Moi. This was serious, since the Electoral Commission's powers were far-reaching. Its functions included not only the preparation and supervision of the elections, the maintenance and revision of voters' registers, and the promotion of voters' education, but also the determination of the number and boundaries of constituencies based on the most recent census: the one of 1989 (Kenya 1992a). It is the latter responsibility which may have decisively influenced the outcome of the parliamentary election in KANU's favour.

There are two ways in which manipulation is possible by means of defining constituencies. The first one is known as 'gerrymandering': the boundary of a constituency is drawn in such a way that the group one does not want to win forms a minority. ${ }^{6}$ Even though there were allegations of 'Moimandering' (Finance, 15 Nov. 1994), it is doubtful whether this actually happened because of the ethnic homogeneity of nearly all districts, and hence constituencies, at least outside the main urban centres.

That cannot be said of the second manipulation method, namely the determination of the number of constituencies, or more specifically the degree of representation per district. According to the Constitution of Kenya, chapter III, section $42(3)$, 'all constituencies shall contain as nearly equal numbers of inhabitants as appears to the Commission to be reasonably practicable.' In 1966, 158 constituencies were created and in 1987 another 30 were added. Although at the time of the expansion of the number of seats, KANU was still the only political party, it is conspicuous that it created a surplus of small constituencies (in terms of population) in areas with strong support for the ruling party.

On average, there should have been about 42,000 voters per constituency ( 7.9 million registered voters divided by 188 parliamentary seats). Reality was very different, however. North-eastern Province (141,000 voters), a KANU stronghold, allocated 10 constituencies (on average 14,100 voters per seat), while Nairobi $(674,000$ voters), an opposition stronghold, counted only 8 seats (more than 84,000 voters per constituency). A district like Taita Taveta (66,900 voters), another KANU stronghold, had four constituencies, while Kisumu Town (100,000 voters), a FORD-Kenya stronghold, was just a single constituency. There are many more examples, all pointing in 
the same direction: areas where KANU was known to be strong (Rift Valley, Coast Province and the sparsely populated areas in the north) are quite over-represented in the Kenyan parliament. This explains why KANU, with only 34 per cent of the votes in the parliamentary election, was able to win 53 per cent of the seats. Seats won by KANU required on average about 33,000 registered voters as against 52,000 for the opposition. If constituencies had becn defined on a more equal basis, the balance in parliament between KANU on the one hand, and the joint opposition on the other, would have been reversed, meaning the opposition would have had a majority of seats.

There is another method of legal manipulation, which may not have such a direct impact as the previous one, but which can influence the outcome in an indirect way. This concerns control by the different political parties of the mass media and particularly television. There are two national television companies in Kenya. The oldest one is the Kenya Broadcasting Gorporation (KBC), which is state owned. The other one is the Kenyan Television Network (KTN), which is owned by KANU. In other words, television is avowedly pro-government. That cannot be said of the press, however. The biggest newspaper, The Daily Nation, is independent, the second largest, The Standard, takes a 'central' position, while the third one, The Kenya Times, is owned by KANU. Moreover, among the weeklies and monthlies there are some highly critical journals, which are widely read.

Finally, legal manipulation can also take place by announcing popular policy measures shortly before election day. This was the case at the annual Jamhuri Day, two weeks before the election of 29 December 1992. Minimum wages for all workers went up by 12 per cent, married women in the civil service were awarded house allowance (a very sensitive point in Kcnya), travelling allowances for Muslims going to Mecca were more than doubled, and over 4,500 prisoners serving sentences of up to six months were released. That same Jamhuri Day, which is supposed to be a national celebration, turned into an outright KANU rally (covered by television, of course), prompting sevcral foreign diplomats (among whom the ambassadors of the United States, Germany and Sweden) to demonstratively leave the Nairobi stadium where it was held. 


\section{ILLEGAL MANIPULATION}

As said, the above-mentioned ways of legal manipulation did not receive very much attention from the press, the opposition and others. More criticisms could be heard regarding various types of illegal manipulation. This concerns not only all kinds of irregularities on election day itself (see below), but also events during the preparation stages in the months prior to the actual elections to which we will turn now.

Complaints started as soon as the registration of voters started on 8 June 1992. According to the opposition, malpractice was widespread and the Electoral Commission disorganized; hence, they called for a boycott. When nothing happened, the opposition decided to make the best of a bad job, and registration went on for 43 days (in 1988 it took three months!). The final deadline came amidst widespread complaints, especially in Nairobi, from people who said they had not been able to obtain identity cards, which are a prerequisite to registration. The relatively short period of voter registration may have been the cause for the low number of voters that were registered in the end: 7.9 million. Compared with an adult population of about 11 million, one can only conclude that at least a few million potential voters were not registered.

The essential questions, then, are: where did most of these unregistered voters live? Or: to which ethnic groups did they belong? Or: did KANU benefit from the non-registration of so many potential voters? According to Africa Confidential (of 18 Dec. 1992), the latter question should be answered with a 'yes'. At district level, this cannot be confirmed, however. Compared with the total populations in all districts, voters' registration ranged from a low 25 per cent in Kwale District to a 'high' 56 per cent in Mombasa District. But one cannot find evidence that registration in 'KANU districts' was higher than in 'opposition districts'.

As for the nomination of candidates for the parliamentary election, the story was different, however. There were reported incidents of violence, abductions and obstructions directed mainly at opposition candidates during the parliamentary and civic nominations in December. A number of opposition candidates were physically prevented from presenting their 
nomination papers in their constituencies, particularly in Rift Valley Province, which many KANU activists had declared a 'KANU zone'. The opposition leaders demanded from the Electoral Commission a repeat of the nominations in all areas where the opposition had cried foul. Strong protests also came from the Commonwealth observation team, as well as from several diplomatic missions. The only thing Chesoni was prepared to do was set up a five-man commission, composed of members of the Electoral Commission, with the task of investigating the reported irregularities. The final result was, first, that the cases where candidates had been physically obstructed from presenting their nomination papers fell outside the authority of the Commission and had to be referred to the High Court and, second, that in the 16 constituencies where opposition candidates had not presented their papers, the Commission had decided that the KANU candidates would stand unopposed, thus giving KANU a comfortable head start.

Several other irregularities and malpractices were reported, mostly shortly before and on election day. Some of these were directly attributable to the Electoral Commission. For instance, a number of polling stations opened with a considerable delay in some cases as late as the afternoon - due to the late arrival of election materials, mainly ballot boxes, ballot papers and stamps. There were also cases where the names of some party candidates were omitted from the ballot papers, but nevertheless voting went ahead in the constituencies concerncd. In some places ballot papers destined for one constituency ended up in a different constituency. In over 40 constituencies, the number of presidential and parliamentary ballots failed to match by more than 800 papers (equivalent to a ballot box full of papers), which is regarded as a characteristic sign of ballot box stuffing. Finally, vote counting and release of results were also seriously delayed. In all, a representative of one of the major observer teams, the Washington-based International Republican Institute, was openly wondering whether the whole process was 'systematic or indicative of a focused effort to disadvantage specific regions, constituencies or candidates' (The Weekly Review, I Jan. 1993: 48).

There were also irregularities which fell outside the responsibilities of the Electoral Commission. Among these were harassment and intimidation of voters - particularly by the Youth of 
KANU '92 (YK '92) - and vote buying. The latter took place on a large scale, predominantly by YK' 92 and the other KANU support groups Operation Moi Wins and Toroitich Till 2000 (Toroitich is Moi's middle name). Unlike the opposition parties, KANU disposed of large sums of money (state money, according to many), and was, for instance, able to set up national and provincial secretariats for its support groups with full-time staff. An estimated US $\$ 60$ million was spent on vote buying, mostly by KANU supporters. Expenses ranged from hiring transport for voters and bodyguards for candidates, to employing thugs and distributing party T-shirts or even cash money to passers-by.

\section{OBSERVATION}

Not only in Kenya itself, but also from the perspective of the donor-countries, the 1992 elections were seen as a major event in the process of democratization. After all, Moi had to agree with multi-partyism and elections after maximum external pressure, notably by suspending foreign aid. Hence, in order to restore the financial relations between Kenya and its donors, the elections had to be labelled 'free and fair'. This explains the great interest in the elections from outside Kenya.

There were several international observation teams. Besides the above-mentioned International Republican Institute (IRI) team, there were officials of two other institutions from the United States, namely the Federal Electoral Commission and the International Foundation for Electoral Systems (a third American-based group, the National Democratic Institute, had been rejected by President Moi because of its supposed bias in favour of the opposition). Another important group was the Commonwealth team, led by Sir Telford Georges, a former chief justice in Zimbabwe and Tanzania. The Commonwealth team was the largest ever sent out by the body on such an assignment, which was in Kenya considered an indication of the seriousness with which the conduct of the elections was being regarded in the Western world. There were also national teams from Canada/Sweden (the so-called Scancan team), Denmark, Egypt, Finland, Germany, Japan, the Netherlands and Switzerland. In all, more than 150 external observers watched the elections. 
The most important local observation team was the National Election Monitoring Unit (NEMU), consisting of several professional and church-related organizations in Kenya. Funded by external donors and chaired by Rev. Samwel Kobia (Secretarygeneral of the National Council of Churches of Kenya), NEMU was set up to coordinate local bodies planning to monitor the forthcoming elections and to educate the public on matters relating to the holding of free and fair polls. Among the 20 members of its 'council of elders' were a former governor of the Central Bank of Kenya, two former permanent secretaries and a leading banker, which were intended to give NEMU muchneeded credibility. Other local monitoring groups were the Bureau for Education, Research and Monitoring, the National Council of Women of Kenya and the National Committee for the Status of Women in Kenya.

At this point it is important to distinguish between observation and monitoring. Usually the distinction is made by the length of the period during which the election process is being watched. Observation, then, is restricted to the actual election day(s) and (part of) the counting of the votes during the day(s) afterwards. Monitoring covers a much longer period and includes the months prior to the actual election day(s). All international teams wcre observation teams (although the IRI organized two missions to Kenya in order to get at least an impression of the nomination process and the campaigns), while the local teams were more of the monitoring type. Interestingly, the Electoral Commission of Kenya used the official status of the person involved as the distinctive criterion, an observer simply being 'a spectator' but a monitor 'almost [being] an official participant within the polling station at which he/she must exclusively operate' (Kenya 1992b: 1). According to the Commission, observers should in particular scrutinize the following aspects of the actual elections (Kenya 1992b: 2-3):

- maintenance of peaceful and orderly voting process;

- documentation and recording of accountable equipment and papers;

- display of empty boxes beforc voting;

- scaling before and after polling;

- transportation of ballot boxes from the polling stations to the counting centres; 
- checking of the seals to the aperture and elsewhere before opening of ballot boxes;

- noting the sealed packets of accountable stationery from the polling stations and the presiding officers' statement of ballot papers issued;

- the manner in which votes are counted;

- collating and correlating of results; and

- visible indication that the presiding officer is in control of the entire polling situation.

On the day the Commonwealth team arrived in Kenya - on 16 December, two weeks before the election day - the IRI just released a press statement of findings on the campaign and nomination process. The report was based on a two-week observation mission and was fairly negative, stating for instance that the electoral process had been 'severely damaged by the centralized and systematic manipulation of the administrative and security structure of the state to the ruling party's advantage' (The Weekly Review, 18 Dec. 1992: 14). The statement also spoke of 'political harassment' of opposition candidates and 'illegal' use of KANU money to influence voters. There was a furious reaction from the YK '92 chairman, Cyrus Jirongo, heatedly accusing the IRI of siding with the opposition, asking the Electoral Commission to cancel the accreditation of the US team and deport them, and if not, threatening to bar the IRI observers from visiting polling stations on polling day (a threat which could not be seen as entirely imaginative).

At the same media briefing, the spokesperson of the IRI team, Margaret Thompson, also stressed that the observer teams were in Kenya to observe and report, not to monitor the polls. As she explained, monitoring would mean virtually overseeing the whole election process (at least a period of six months), whilc observing involved mainly placing personnel at selected stations in order to get an impression of whether or not the polls were free and fair. But even within this limited scope, this was precisely one of the major weaknesses of the observation process, because there were far too few international observers. The result was that only a minority of all polling stations could be visited by the observation teams, and the time spent at each station was usually very short, certainly not the 
whole day. This can be exemplified by the following account (Geisler 1993: 620):

In Kenya, covering an area more than twice the size of Britain, 160 international observers were confronted with over 7,000 polling stations (roughly 45 for each of them), not to mention the 10,500 or so 'streams' with their separate voting procedures. The 56 members of the International Republican Institute managed to visit 2.3 per cent of the polling stations in a quarter of all constituencies, while the 33-strong Commonwealth Observer Group claimed to have seen roughly three per cent of all polling stations in 75 per cent of the 188 constituencies. The coverage of other observation missions was altogether more patchy. A Swedish team of four, for example, visited 22 stations in two constituencies, and others did not fare much better.

The observation team from the Netherlands consisted of seven representatives from the Ministry of Foreign Affairs in The Hague. The large majority of them had had experience with or in Kenya before, which was felt as 'very useful'.? According to the terms of reference, the mission's observations only concerned the election day itself and, to a limited extent, also the counting of the votes. More specifically, the aspects which were to be watched in particular were the opening of the polling station (including the sealing of the ballot boxes), the closing of the ballot boxes, the transportation of the ballot boxes to the central counting station, as well as the start of the counting of the votes.

Together with a representative from the Netherlands Embassy in Nairobi, each team member 'covered' a specific area in Kenya. These were parts of the following districts: Nairobi, Embu/Meru, Laikipia, Kajiado, Uasin Gishu/Elgeyo Marakwet, West Pokot, and Turkana (the former three being opposition strongholds and the latter four being KANU strongholds). In all, the seven teams visited 68 polling stations and 9 counting offices. Most stations opened too late, some even in the afternoon, the main reason being late arrival of ballot boxes and papers due to transport problems. In several stations, there was a shortage of ink and stamps, in a few also of ballot papers. The lack of privacy was conspicuous in the eyes of the Western observers: the voting booths were hardly screened, while the il- 
literates (of which there are many, especially in the rural areas) had to be aided by the officials. Nevertheless, the observers' impression was that the voters seemed not to have any problem with this lack of privacy while casting one's vote. In all polling stations, NEMU observers were present, although many of them were very young and remained quite 'invisible' during the election day. Also present in most stations were 'agents' of the four major political parties. In a few cases, it was witnessed that these agents played a rather intimidating role towards the illitcrate voters. Finally, in one of the districts, people from a nearby refugee camp (victims of the 'ethnic clashes' during the campaigns) were not given the opportunity to vote, despite their strong wish to do so.

The counting of the votes took place with an enormous delay, for several reasons. First, many polling stations closed later because their opening was delayed. Second, some presiding officers did not give permission to start counting before all ballot boxes had arrived, which because of the transport problems took many hours. Third, the whole counting process was very inefficient, partly because of the exaggerating attempts to let it look 'transparent'. In addition, it was observed that no specific identification had been attached to the ballot boxes brought in, although this was legally prescribed. It was also noted that party agents did not check the numbers on the ballot boxes, even though they had written these down in the morning. This check would have been the only proof that the boxes had not been opened between times.

Despite all these imperfections, the judgement of all seven sub-teams was moderately positive. The general 'impression' was that, despite the fact that many voters had to queue for hours in the hot sun, the people had been able to cast their votes in the way they intended to. There were hardly any irregularities noticed. It was also felt that voters and officials, as well as party agents, were very positive regarding the presence of the international observers.

Of major concern for the Kenyan government were the final statements by the international observation teams. In private, none of the international monitoring teams and virtually no Nairobi-based diplomats could state that the elections had been fair. In its official statement released on the eve of its departure (when, according to Geisler 1993, the counting of the votes 
had not yet been concluded in many constituencies!), the Commonwealth team even admitted this:

This was an election that proved difficult to evaluate in terms of frceness and fairness. It was evident to us from the start that some aspects of the election were not fair. These included:

- the registration process in many parts of the country;

- the nomination process, particularly in the Rift Valley, resulting in the unopposed return of $16 \mathrm{KANU}$ parliamentary candidates;

- the lack of transparency on the part of the Electoral Commission;

- the intimidation, administrative obstacles and violence that marked the political campaign;

- the partisanship of the state-owned radio and television;

- the reluctance of the government to delink itself from the KANU party.

These negative aspects were compounded by the numerous administrative problems that can be directly attributed to the inability of the Electoral Commission to plan ahead and pay adequate attention to the many basic and essential elements of the electoral process. This resulted in late delivery of materials, polls with too many voters, lack of adequate training officials and a non-effective public education programme. (The Weekly Review, l Jan. 1993: 9)

The statement went on in a more positive tone by stressing the inexperience of the Electoral Commission, the dedication and enthusiasm with which the millions of people had exercised their right to vote, the commitment of the thousands of polling officials, and so on. Its main conclusion was that the elections constituted 'a giant step on the road to multi-party democracy'. The latter was underscored in the official statements of all other international observation teams, including the one from the Netherlands. However, some additional remarks in the report of one of the seven Dutch sub-teams may be revealing. From reliable sources in the district concerned it became clear that strong manipulation practices had occurred during the period before the elections, with the sole aim to limit the antiMoi and anti-KANU votes in the district. Examples were high 
payments to potential opposition candidates who were willing to withdraw, harassment of (potential) candidates, and opposition offices pelted with stones.

The national monitoring teams had between 7,500 and 10,000 observers deployed in the field, and their judgement of the actual elections was much more critical than that of the international teams. Almost immediately after the election day, the largest, the National Election Monitoring Unit (NEMU), declared that the "electoral process has been seriously compromised' and in its final report the unit concluded 'that the December 1992 elections were not free and fair' (Geisler 1993: 627).

\section{THE 1997 ELECTIONS ${ }^{8}$}

Exactly five years after the 1992 elections, the next elections were held. Before presenting the results, it is important to (briefly) discuss the developments prior to polling day. These can best be dealt with in terms of changes on the one hand and continuities on the other. The continuities refer to renewed ethnic clashes and to a divided opposition. The changes concern the political reforms of September 1997 and the monitoring activities by the donor community.

In August and September 1997, very serious ethnic conflicts emerged at the Coast and later in the south-west as well. The resemblance with the clashes that occurred in Rift Valley Province in 1992 was conspicuous. First, the attacks were carried out by large, well-organized groups. Second, the violence involved was very brutal, and hundreds of people were killed. Third, the violence at the Coast was solely directed at people from up-country: people known to vote for the opposition in an area dominated by KANU. Finally, the cases were never solved: it never became clear who the real leaders were, let alone that any of the perpetrators were tried in a court of law.

The opposition was even more divided than during the 1992 elections. There were 14 opposition candidates for the presidency, while 24 parties took part in the general elections. The two FORD parties fell further apart. FORD-Kenya - in 1992 a coalition of the Luo and part of the Luhya communities - split into two because the Luo political lcader, Raila Odinga (son of 
the late Oginga Odinga) stepped out to form his own Luo party, the National Development Party (NDP). Hence, FORD-Kenya became a Luhya party led by Kijana Wamalwa. The same happened with FORD-Asili, which combined part of the Kikuyu and part of the Luhya communities. Partly because its leader, Kenneth Matiba, refused to stand for the presidential elections, the party split into a Luhya faction (FORD-Asili) and a Kikuyu faction (FORD-People). Several other parties took part in the clections, two of which were of some importance, notably the Kamba-based Social Democratic Party (SDP, with the first female presidential candidate Charity Ngilu) and Safina, the only party which pretends to have a non-ethnic base (hence its name, which means 'the Ark'). The largest ethnic group in Kenya, the Kikuyu, was also the most divided one, since there were five Kikuyu candidates for the presidency, although only one of them, Mwai Kibaki (Democratic Party), was a serious one.

An important change compared with the previous elections concerned the constitutional and legal reforms of September 1997. For years KANU had refused to comply with the widelyvoiced desire - under the leadership of the NCEC, the National Convention Executive Council, representing a broad range of church-related and other societal organizations - for political reforms in the country. However, in order to avert complete chaos, a group of about 75 members of parliament from both KANU and the opposition parties decided to take the initiative by forming the so-called Inter-Parties Parliamentary Group (IPPG), which had to formulate a wide range of constitutional and legal reforms. Among the more important reforms were the extension of the Electoral Commission by 10 members suggested by opposition parties (but still forming a minority against the 11 members from KANU), the provision for a coalition government (in practice meaning that the president can appoint ministers in his cabinet from opposition parties, which is precisely the way Moi became a minister in 1964), the recommendation to register all parties (which led to the registration of Safina but not of the Coast-based Islamic Party of Kenya), and the equal allocation of broadcasting time for all parties on television and radio. However, two issues of decisive importance for the election results and for the power distribution in the country were left untouched. This was the 25 per cent rule for the presidential elections and the determination of the con- 
stituency boundaries (by the Electoral Commission); hence the general conclusion of the NCEC that the reforms 'are massively deficient in ensuring a representative parliament for Kenyans' and that it is 'not possible to achieve free and fair elections under these conditions' (The Sunday Nation, 14 Sept. 1997).

Another important change was in the field of monitoring and observation of the electoral process. Initiated and coordinated by the Dutch embassy in Nairobi and chaired by the Canadian embassy, a group of 22 donor-countries (also including the United States, Britain, France, Germany, Japan and the Scandinavian countries) formed the Donors' Democratic Development Group (DDDG) in order to monitor the whole election process, including such critical phases as voter registration, party primaries, nomination of candidates, political campaigning, the polling itself and counting (see Rutten below). The reason to do so was the conviction that manipulation did take place in 1992, perhaps not so much during the actual elections but during the preceding stages. The actual monitoring was carried out by a group of researchers from various donor countries (the Election Observation Centre or EOG), as well as by teams from the diplomatic missions. Voter registration, party primaries and nominations of candidates were followed in 25 districts. Presidential and parliamentary campaign meetings were attended in all provinces except one (North-eastern). On election day, 90 teams visited over 500 polling stations in 118 (of the 210) constituencies and counting was monitored in 50 counting halls (DDDG 1998).

At the national level, the 1997 elections were observed by a group, funded by several European countries, whose motto was 'Together for Peaceful Elections' and consisting of the National Council of Churches of Kenya (NCCK), the Institute for Education in Democracy (IED) and the Catholic Justice and Peace Commission (CJPG). Just like the donor community, not only the poll itself was observed - by over 28,000 watchers, working in teams of two in all the 210 electoral constituencies and of three present at the counting centres - but also the voter registration, the nomination process, the campaigns and the role of the media, by 840 monitors (The Weekly Review, 9 Jan. 1998).

Because of the splintered opposition, largely along 'tribal' lines, the results of the 1997 election were very much like those 
of the previous polls. In the presidential election, Moi won most votes (40 per cent) and was again the only candidate with more than 25 per cent of the votes in five of the eight provinces. The only serious rival was Kibaki, who got 30 per cent of the votes, with more than 25 per cent in three provinces. The three other candidates who prior to the polls were also seen as rivals Odinga, Wamalwa and Ngilu - were far behind and only managed to get a substantial number of votes in their 'home' provinces. In the general elections, KANU again won the majority of the seats, notably 107 out of 210 (against 100 out of 188 in 1992), of which 11 unopposed. Kibaki's Democratic Party won 39 seats (23 in 1992), Odinga's National Development Party 21 and Wamalwa's FORD-Kenya 17 (against 31 in 1992 for the two combined), while newcomers Social Democratic Party and Safina won 15 and 5 seats, respectively. ${ }^{9}$ The ethnic factor in both the presidential and the parliamentary elections is clear again: Kibaki and his DP profited from the withdrawal of Matiba, thus obtaining many votes from that part of the Kikuyu-Embu-Meru cluster that voted for Matiba and his FORD-Asili in 1992. Both the NDP and FORD-Kenya are much smaller now than the original FORD-Kenya in 1992, because of the split of the latter in a Luo and a Luhya party, respectively.

The election itself was described as 'chaotic'. According to The Daily Nation of 30 December 1997, just about anything that could go wrong did go wrong'. ${ }^{10}$ The newspaper talked about a 'Chaplinesque performance', a 'national disgrace' and 'an insult to voters', but admitted that not only the Electoral Commission was to blame for this, but certainly also the extremely bad weather. In a first analysis of the 'Together for Peaceful Elections' group, it was stated that 56 per cent of the polling stations failed to open on time, because voting matcrials were not available or election officials were not present. The poll watchers reported concerns about the lack of secrecy in about 6 per cent of the stations. Also during the nomination process and the political campaigns, many irregularities had been observed, mostly bribery and vote buying, particularly by 'the ruling party'. On the other hand, the voting itself was reported to have taken place in 'a serious and largely satisfactory manner'. The same applied to the counting process. The group's general conclusion was that despite the many irregularities and the chaotic character of the elections, 'the results 
reflected the wishes of the voters'. At the same time, however, it was recommended that the institutional bias for KANU, such as the domination of the state media and the unfair delineation of electoral constituencies, ought to be seriously addressed (The Weekly Review, 9 Jan. 1998). Much more critical were the NCEC, the Kenya Human Rights Commission (KHRC) and the Citizens Coalition for Constitutional Change (or '4Cis'). They rejected the results as null and void, demanding new elections (The Economic Review, 5 Jan. 1998).

In its final report, the DDDG (1998) also mentioned irregularities during the various stages of the clection process. About four million potential voters were not registered as such: two million aged 18-23 who had not been issued identity cards and another two million who just failed to do so. However, as in 1992, there was no proof that non-registration occurred more in opposition than in KANU areas. The party primaries were 'peaceful and transparent' in most areas, although problems were evident in several others. On the whole, the primaries were 'flawed but acceptable'. The nominations of parliamentary candidates on 8 and 9 December went 'satisfactorily', although in a number of areas there was violence and tension. As in 1992, media coverage of the campaigns was very disproportionately in favour of KANU and president Moi, notwithstanding the reforms regarding this point by the IPPG. Moreover, opposition coverage by the two national television channels (KBC and KTN) was negative throughout and positive as far as KANU was concerned. Despite the reporting by the written media of the very chaotic character of the voting day, it was established that almost 90 per cent of the 7,500 polling stations on which information was available were well organized. Nevertheless, the DDDG report mentions some serious problems. First, there were cases of misprints and omissions of candidates' names on the ballot papers. Even the Electoral Commission itself had to admit (in a press release of 31 December 1997) that under such circumstances 'it cannot be said such elections were fair'. Second, in 13 per cent of the stations the secrecy of the vote was not guaranteed. Third, bribery and vote buying were common, even on election day. Counting of the votes was generally conducted 'in a fair and transparent manner', albeit that there were substantial delays largely due to ill-prepared returning officers. In eight constituencics, however, serious irregularities were 
noticed. In three of these - Westlands (Nairobi), Kitui West (Eastern) and Changamwe (Mombasa) - the KANU candidate narrowly won under very suspicious circumstances. This is the more serious because otherwise the combined opposition would have had the majority of the seats in parliament instead of the ruling party. The counting of the votes for the presidential elections was 'satisfactory' in most constituencies.

Despite all this, on 7 January 1998 the European Union released a statement through its president, the British High Commission in Nairobi, saying that it accepted the results of not only the presidential but also the parliamentary elections, describing it as 'a further step in Kenya's development towards greater democracy'. At the same time it was noted that the elections fell short of 'normal democratic standards', that there were incidents of violence, bribery and intimidation of voters. Moreover, 'voter registration was incomplete, the media, the $\mathrm{TV}$, and radio controlled by the State did not provide balanced coverage' (The Daily Nation, 8 Jan. 1998).

\section{CONGLUSION}

As in most other African countries, ethnic rivalries play an overwhelming role in Kenyan politics. In such a system, political parties play a role as vehicles in order to get access to the political centre and, hence, to state resources. The easy switching by candidates for the parliamentary nominations from one party to another is telling in this respect. With them, the voters switch as well. FORD-Kenya is a clear illustration: in 1992 it was a Luo party with some Luhya support, but with the defection of the main Luo political leader, it became a pure Luhya party and lost in 1997 all its support in the province in which it won overwhelmingly in 1992.

The practice of ethnic voting makes it possible to determine to a certain extent cach party's strong and weak electoral areas. In a constituency voting system after the British example, combined with control by the ruling party of the Electoral Commission, this can easily lead to (legal) manipulation and constituency boundaries which strongly favour KANU. Besides several other legal and illegal manipulation practices, this was 
a major factor in KANU's large victory in the parliamentary elections of 1992.

Does election observation make sense in a system in which the outcome of the elections is to a certain extent known in advance? That was a key question after the 1992 elections. It was felt that because the major manipulation practices took place during the stages prior to the actual polling day, monitoring of the whole election process was necessary, and in as many areas as possible. Five years later, this was indeed done by both a national monitoring group ('Together for Peaceful Elections') and a group of 22 donor-countries (the Donors' Democratic Development Group). For the latter group, this was a unique 'experiment' leading to a critical report in which many irregularities were noticed. A careful reader of the report can only come to the conclusion that the 1997 elections were not really 'free and fair' and that the results of the parliamentary election (not the presidential election) are at least questionable.

It is still too early to say what lessons can be drawn from this 'experiment', not only for the group of donor-countries but also for election observation in general. It is beyond question that such monitoring is far more useful (but also far more expensive) in assessing the 'free and fair'-ness of such elections than short-term observation alone. But the main question that remains is whether the whole election process was positively influenced because of monitoring activities by the two monitoring groups. What is clear is that despite the monitoring activities, the election process was not entirely 'free and fair'. Nevertheless, two tentative conclusions can be drawn from the DDDG 'experiment'. First, in its role as an objective 'third party', it is likely that at least it prevented the election process from being even more 'unfree and unfair'. And second, it served to legitimize the role of the local monitoring organizations.

\section{NOTES}

1. This section is based on data derived from the Population Censuses of 1969, 1979 and 1989. We are grateful to Deborah IJsendijk and Luuk Dietz for their assistance with data collection and analysis.

2. An ethnic cluster consists of one or more 'ethnic groups' as distinguished by the Kenyan Central Bureau of Statistics during the 
Population Census of 1989. For instance, the Kikuyu, Luhya, Luo, Kalenjin, Kamba, Somali and Turkana are all different ethnic clusters, while the Kisii, Maasai, Coastal Bantu, Meru and Boran are clusters consisting of more than one ethnic group.

3. It is quite easy to define 'home areas' since the Kenyan Districts are demarcated along ethnic boundaries. For instance, the Kikuyu home area constitutes Kiambu, Murang'a, Nyeri, Kirinyaga and Nyandarua Districts, the Luo home area consists of Kisumu, Siaya and South Nyanza Districts, whilc the Somali home area is made up of Garissa, Mandera and Wajir Districts. Only Nairobi and Mombasa are exceptions to the rule. It should be noted that the 'original' 40 districts are used in this analysis: before the many subdivisions that started at the end of the $1980 \mathrm{~s}$.

4. Kwale: Coastal Bantu ( 85 per cent, 84 per cent and 85 per cent in 1969, 1979 and 1989, respectively); Kilifi: Coastal Bantu (94-93-93); Tana River: Coastal Bantu (64-39-42); Machakos: Kamba (98-97-97); Embu: Meru cluster (89-86-86); Garissa: Somali (96-83-91); Mandera: Somali (96-89-98); Wajir: Somali (98-92-98); Murang'a: Kikuyu (96-96-96); Nandi: Kalenjin (78-71-74); Bungoma: Luhya (84-81-83); and Busia: Luhya (65-60-61). NB: figures are rounded.

5. Mombasa: Coastal Bantu (35-37-40); Kirinyaga: Kikuyu (96-97-97); Nyandarua: Kikuyu (95-95-96); Laikipia: Kikuyu (57-64-68); Samburu: Maasai cluster (74-75-75); Kericho: Kalenjin (82-83-83); and Trans Nzoia: Luhya (47-49-52)

6. The term 'gerrymandering' is derived from an American governor, Eldridge Gerry of Massachussets, who concoctcd a constituency that looked like a salamander. Well-known examples could also be found in Northern Ireland, where boundaries cut Catholic neighbourhoods in two, so that in both constituencies the Protestants formed a majority.

7. The information concerning the Dutch observation team is derived from Memorandum - 02/93, The Hague: Ministry of Foreign Affairs, 5Jan. 1993.

8. Since this section was written shortly after the elections, only first impressions can be presented here.

9. The remaining six seats went to FORD-People (3), FORD-Asili (1), Kenya Social Congress (1) and the Shirikisho Party of Kenya (1). In addition, twelve members of parliament were nominated: six for KANU, two for the DP and one for NDPK, SDP and Safina. The fact that half of the nominated members were proposed by the opposition was one of the results of the political reforms of September 1997, because in 1992 all twelve were KANU representatives. In all, KANU now occupies 113 seats in parliament and the combined opposition 109.

10. Ballot boxes arrived too late, were insufficient and/or improperly secured. Ballot papers were not present at all, or too few or the wrong ones or with the wrong symbols or with no names, and so on. Polling stations could not open as no security guards were at hand or no officials turned up or staff wanted more money. Hence, in a number of polling stations people could vote the next day as well. 


\section{REFERENCES}

DDDG, 1998. Final Report: Kenya General Elections 1997 (Nairobi: The Donors Democratic Development Group).

Dietz, T., D. Foeken and A. van Haastrecht, 1996. Kenya: Mensen, Politiek, Economie, Cultuur (Amsterdam/The Hague/Brussels: KIT/Novib/NGOS).

Doornbos, M. 1991. 'Linking the Future to the Past: Ethnicity and Pluralism', Review of African Political Economy 52: 53-65

Focken, D. and T. Dietz, 1993. 'Leidt Afrikaanse Democratisering tot Etnische Polarisatie?', Geografie 3(1): 30-4.

Fox, R. 1996. 'Blcak Future for Multi-Party Elcctions in Kenya'. The Journal of Modern African Studies 34(4): 597-607.

Geisler, G. 1993. 'Fair? What has Fairness got to do with it? Vagaries of Election Observations and Democratic Standards', The Journal of Modern African Studies 31(4): 613-37.

Haugerud, A. 1995. The Culture of Politucs in Modern Kenya (Cambridge: Cambridge University Press).

Holmquist, F. and M. Ford, 1992. 'Kenya: Sloughing toward Democracy', Africa Today 39(3): 97-111.

Hornsby, C. and D. Throup, 1992. 'Elections and Political Change in Kenya', Journal of Commonzealth and Comparative Politics 30(2): 172-99.

IED, 1997. National Elections Data Book Kenva 1963-1997 (Nairobi: Institute for Education in Democracy).

Kenya, Government of, 1992a. Election '92: Towards Free and Fair Elections (Nairobi: Ministry of Foreign Affairs and International Cooperation).

Kenya, Government of, 1992b. The Role of Election Observers and the Code of Ethics (Nairobi: Government Printer)

Kenya, Government of, 1994. Population Census 1989 (Nairobi: Ministry of Planning and National Development/Office of the Vice-president, Central Bureau of Statistics)

Lemarchand, R. 1992. 'African Transitions to Democracy: an Interim (and Mostly Pessimistic) Assessment', Africa Insight 22(3): 178-85.

Osaghae, E.E. 1993. 'A Re-examination of the Concept of Ethnicity in Africa as an Ideology of Inter-elite Competition', African Study Monographs 12(1): $43-60$.

\section{Periodicals and Papers}

Africa Confidential, various issues.

The Daily Nation, Nairobi, various issues.

The Economic Revnew, Nairobi, 5 Jan. 1998.

Finance, Nairobi, 15 Nov. 1994.

The Sunday Nation, Nairobi, 14 Sept. 1997.

The Weekly Review, Nairobi, various issues. 